\title{
Klasifikasi Citra Daun Memanfaatkan Angular Partition, Edge Detection dan Neural Network
}

\author{
Elkana Lewi Santoso, STT Cahaya Surya Kediri, Endang Setyati, Teknologi Informasi iSTTS, dan \\ Yosi Kristian, Informatika iSTTS
}

\begin{abstract}
Abstrak- Penelitian yang dilakukan ini adalah untuk mengklasifikasikan tanaman berdasarkan bentuk daunnya. Terdapat 1907 citra daun berasal dari 32 jenis tanaman yang berbeda. Citra daun tersebut diambil dari website flavia. Proses klasifikasi daun-daun dilakukan dengan menggunakan Neural Network dengan metode Back Propagation Neural Network (BPNN). Tahap awal adalah mengubah ukuran gambar yang didapat dari flavia $1600 \times 1200$ piksel menjadi berukuran 300x225 piksel, terdiri dari tahap membuat gambar dengan Sobel untuk mendeteksi tepi, membuat gambar dengan Sobel dan menambah kecerahan gambar, sehingga tepi dan serat daun dapat lebih jelas. Citra daun di potong-potong dengan angular partition (sudut pembagi) $5^{\circ}, \mathbf{1 1 . 2 5}^{\circ}, \mathbf{2 2 . 5}^{\circ}, \mathrm{30}^{\circ}$, $45^{\circ}$ dan $90^{\circ}$. Pembuatan data set dengan delapan ekstrasi fitur daun yang terdiri dari menghitung: jumlah piksel-piksel pada bagian daun, jumlah piksel pada keliling daun, jumlah sudut pada daun, jumlah piksel pada keliling dan serat daun serta menghitung jarak tiap-tiap piksel tersebut dengan center of gravity (titik berat). Pada penelitian ini dilakukan 100 macam variasi nilai hidden layer untuk tiap-tiap sudut pembagi tersebut. Hasil dari penelitian ini adalah: semakin kecil sudut pembagi $\left(5^{\circ}\right)$ dan semakin besar sudut pembagi $\left(90^{\circ}\right)$ tidak menghasilkan akurasi yang semakin bagus. Hasil akurasi tertinggi yang diraih sebesar $\mathbf{9 6 , 7 4 8 8 \%}$. Hasil tersebut didapat dengan membagi daun menjadi sudut $11,25^{\circ}$ tiap bagian (16 bagian), Susunan BPNN yang digunakan terdiri dari 1 input, 1 output, 3 hiden layer, tiap hidden layer berisi 128, 120, 112 neurons, dan 32 neurons untuk output layer.
\end{abstract}

Kata Kunci-Angular Partition, Back Propagation, Center of Gravity, Neural Network.

\section{PENDAhUluan}

Tanaman adalah makluk hidup yang sangat berperan penting dalam ekosistem. Tanpa tanaman susunan ekosistem pasti akan terganggu dan besar kemungkinan akan musnah. Hal ini dikarenakan tanaman berfungsi sebagai bahan makanan, obat-obatan, bio energy, dan juga sebagai penyeimbang alam karena tanaman juga menghasilkan gas $\mathrm{O} 2$ dan $\mathrm{CO} 2$ selain itu tanaman juga berfungsi sebagai penahan resapan air didalam tanah. Fungsi tanaman sangat penting, tanpa tanaman maka tidak akan ada kehidupan. Ada sekitar 350.000 jenis tanaman di bumi yang telah dikenal. Indonesia terletak didaerah khatulistiwa sehingga mendapat

Elkana Lewi Santoso, Pengajar di STT Cahaya Surya Kediri, Jawa Timur, Indonesia (e-mail: elkanaliu@ cahayasurya.ac.id)

Endang Setyati, Teknologi Informasi Institut Sains dan Teknologi Terpadu Surabaya, Surabaya, Jawa Timur, Indonesia (e-mail: endang@stts.edu)

Yosi Kristian, Informatika Institut Sains dan Teknologi Terpadu Surabaya, Surabaya, Jawa Timur, Indonesia (email: yosi@stts.edu) sinar matahari sepanjang tahun dan curah hujan yang tinggi hal ini sangat menunjang untuk kelangsungan hidup flora dan fauna.

Dengan semakin berkembangnya teknologi dibidang komputer, sehingga komputer mampu mengerjakan tugastugas secara cepat dan simultan. Salah satu perkembangan computer dewasa ini adalah dalam bidang pengenalan obyek (object Recognation). Dalam penelitian ini akan diterapkan teknologi pengenalan terhadap obyek daun. Daun adalah salah satu unsur yang penting untuk mengenali species tanaman[1]. Banyaknya jenis tumbuhan dapat dilihat dengan bentuk daun yang berbeda sebagai ciri yang mewakili jenis tanaman. Sehingga tidak mungkin untuk dihafalkan, oleh karena itu diperlukan suatu aplikasi cerdas yang dapat mengenali berbagai berbagai macam daun.Sehingga diharapkan dapat membantu para ahli biologi, pelajar/mahasiswa dan peneliti lain untuk dapat mengklasifikasikan tanaman berdasarkan bentuk daun.

Dalam penelitian ini, digunakan metode Anggular Partition[2] untuk membentuk ekstraksi karakteristik daun dan Back Propagation Neural Network (BPNN) untuk mengklasifikasikan daun berdasarkan karakteristik bentuk daun.

Angular partition yang digunakan pada penelitian ini sebesar $5^{\circ}, 11.25^{\circ}, 22.5^{\circ}, 30^{\circ}, 45^{\circ}$ dan $90^{\circ}$. Hal ini dilakukan untuk mengetahui berapa besar sudut yang sesuai dan menghasilkan akurasi yang paling besar.

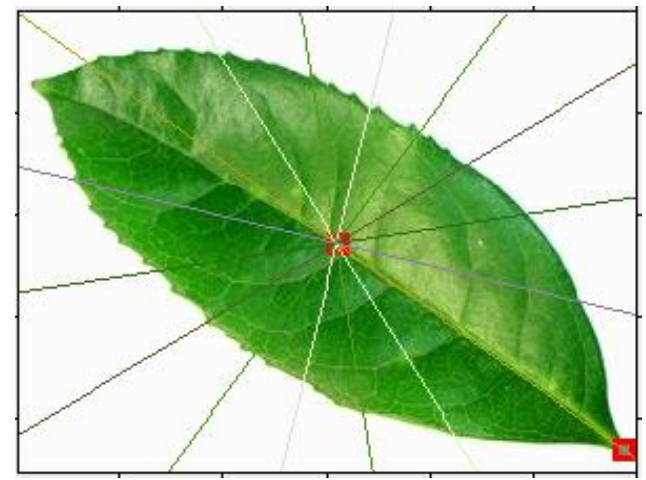

Gambar 1. Daun dengan Angular Partition 22.5

\section{II.PENELITIAN PENUNJANG}

Bab ini membahas tentang teori-teori penunjang yang dipergunakan dalam penyelesaian penelitian. Teori penunjang ini mencakup penjelasan dari beberapa jurnal 
ilmiah yang diambil untuk membandingkan dan menunjang penelitian ini beserta teori umum seperti biner, grayscale, sobel, angular partition, dan BPNN

Pada tahun 2004 Abdolah Chalechale[3], Golshah Naghdy, Alfred Mertins telah meneliti metode untuk angular partition pada sebuah image abstrak, Data set yang mereka gunakan dalam percobaan yaitu sebanyak 365 image full color dengan ukuran yang bervariasi dan 180 dari image sketsa hitam putih sebagian untuk dijadikan data uji dengan dilakukan berbagai rotasi $90^{\circ}, 180^{\circ}$, dan $270^{\circ}$. Data tersebut mereka dapatkan dari World Art Kiosk at California State University.

Pada tahun 2007 Stephen Gang Wu, Forrest Sheng Bao, Eric You Xu, Yu-Xuan Wang, Yi-Fan Chang, Qiao-Liang Xiang menemukan cara mengklasifikasikan daun dengan metode Probabilitas Neural Network (PNN). Penelitian ini dimuat juga pada laman Flavia yang menyediakan kumpulan gambar daun berjumlah 1907 daun yang terdiri dari 32 klas[1]. Dari gambar daun tersebut dilakukan penelitian ini.

Pada tahun 2007 Johann Misterio, Krshna Ravindra, Rene D Rivero, Henry McCloud, Levelle Burr-Alexander, Nuggehalli Ravindra meneliti tentang dimensi fraktal pada daun [4] yaitu suatu bentuk yang sama yang bisa berulang. pada suatu dimensi pada daun. Dari penelitian ini maka dapat disimpulkan bahwa data perbandingan dari jumlah piksel tiap potongan dengan totol semua piksel dari daun yang disebut normalisasi bisa dilakukan pada data set.

Pada tahun 2011 Dimpy Adira Ratu [11], meneliti tentang pengenalan tanaman obat-obatan dengan mengunakan box clustering dan Probabilistic Neural Network (PNN)[1][10][11], Box Clustering digunakan untuk pembentukan data set. sedangkan dalam penelitian ini menggunakan Angular Partition.

Pada tahun 2014 sebuah penelitian yang diterbitkan semantic Schoolar yang ditulis oleh Kesari Verma, Ligendra Kumar Verma, dan Priyanka Tripathi menemukan BPA (Back Propagation Algorithm) adalah salah satu satu teknik kategorisasi image yang paling sesuai, karena semua vektor fitur tersedia dalam bentuk numerik. eksperimen yang telah dilakukan menemukan bahwa ketepatan klasifikasi juga bergantung pada hidden layer dan epoches [12]

Dari penelitian-penelitian tersebut maka pada penelitian ini dilakukan penelitian klasifikasi citra daun dengan pembagian sudut pada struktur permukaan citra daun dan metode backpropagation untuk proses pengklasifikasian citra daun tersebut. Citra daun berasal dari flavia web yang berbentuk jpg dan berukuran 1600(p) x 1200 (L) terdiri dari 3 layer RGB. Citra tersebut dikecilkan menjadi berukuran 300x225 tetap berupa RGB. Dari citra hasil resize tersebut dilakukan preprocessing untuk membentuk citra dengan tampak tepi luar daun dan citra dengan tampak tepi luar dan serat daun seperti yang terlihat pada Gambar 3 .

Pada Gambar 2 adalah gambar dari rancangan sistem yang digunakan. Hasil dari ekstraksi fiture dari citra daun disimpan dalam bentuk feature vektor untuk kemudian dilakukan proses klasifikasi dengan persentasi data $70 \%$ untuk trainning, $15 \%$ untuk testing dan $15 \%$ untuk validasi data. Validasi data digunakan untuk memvalidasi bahwa jaringan itu berjalan normal dan untuk menghentikan pelatihan sebelum terjadi overfitting [5]. Dari pembelajaran klasifikasi citra daun pada neural network, didapat simulasi neural network yang dapat digunakan untuk mengklasifikasikan citra daun lain sebagai citra uji.

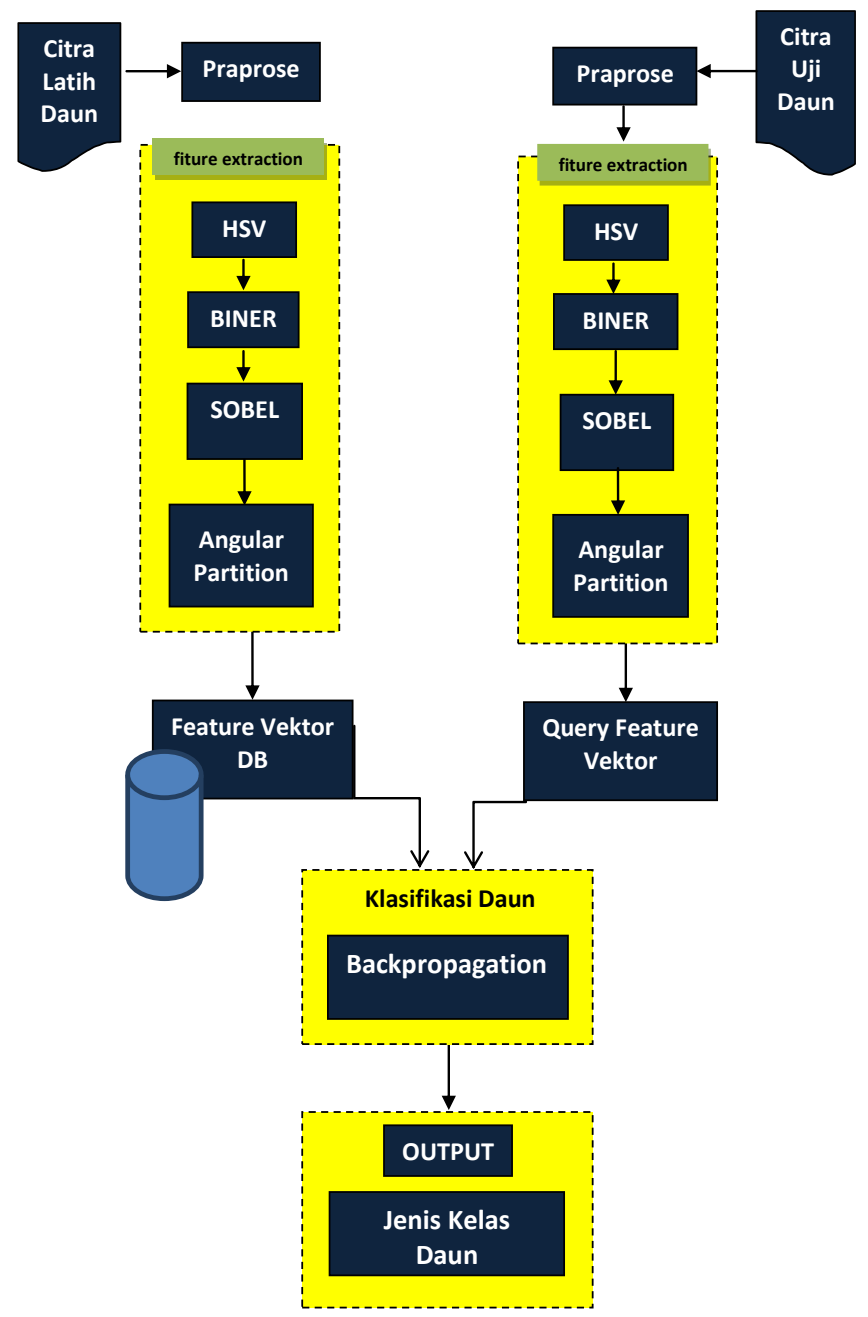

Gambar 2. Rancangan Sistem

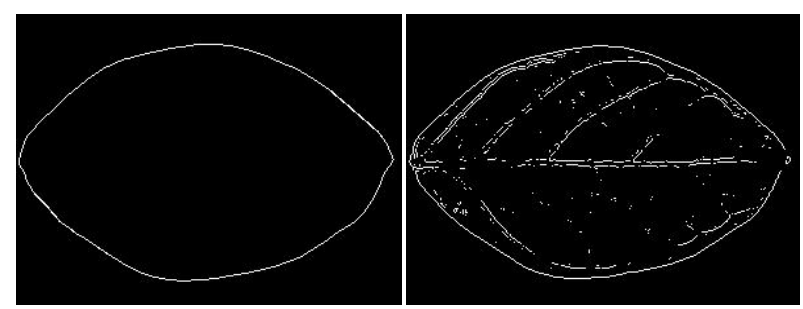

Gambar 3. Citra Tepi Luar dan Serat Daun.

\section{METODOLOGI}

A. DATA SET

Data citra daun diambil dari situs flavia sebanyak 1907 citra yang terdiri dari 32 jenis tanaman seperti yang terdapat pada Tabel I dan akan diresize menjadi 300x225 piksel, Pada semua citra daun tersebut dilakukan proses untuk membuat data set:

1. HSV[9] untuk membuat deteksi tepi agar lebih terlihat jelas.

2. Biner adalah proses untuk menghasilkan citra hitam dan putih.

3. Sobel untuk mendeteksi tepi daun dan serat daun.

4. Angular partition sebesar $5^{\circ}, 11.25^{\circ}, 22.5^{\circ}, 30^{\circ}, 45^{\circ}, 90^{\circ}$. 
TABEL II

DAFTAR DAUN dari 32 JENIS TANAMAN

\begin{tabular}{||c|c|c|}
\hline No. & Common Name(s) & Jumlah \\
\hline 1 & pubescent bamboo & 59 \\
\hline 2 & Chinese horse chestnut & 63 \\
\hline 3 & Chinese redbud & 72 \\
\hline 4 & true indigo & 73 \\
\hline 5 & Japanese maple & 56 \\
\hline 6 & Nanmu & 62 \\
\hline 7 & castor aralia & 52 \\
\hline 8 & goldenrain tree & 59 \\
\hline 9 & Chinese cinnamon & 55 \\
\hline 10 & Anhui Barberry & 65 \\
\hline 11 & Big-fruited Holly & 50 \\
\hline 12 & Japanese cheesewood & 63 \\
\hline 13 & wintersweet & 52 \\
\hline 14 & camphortree & 65 \\
\hline 15 & Japan Arrowwood & 60 \\
\hline 16 & sweet osmanthus & 56 \\
\hline 17 & deodar & 77 \\
\hline 18 & ginkgo, maidenhair tree & 62 \\
\hline 19 & Crape myrtle, Crepe myrtle & 61 \\
\hline 20 & oleander & 66 \\
\hline 21 & yew plum pine & 60 \\
\hline 22 & Japanese Flowering Cherry & 55 \\
\hline 23 & Glossy Privet & 55 \\
\hline 24 & Chinese Toon & 65 \\
\hline 25 & peach & 54 \\
\hline 26 & Ford Woodlotus & 52 \\
\hline 27 & trident maple & 53 \\
\hline 28 & Beale's barberry & 55 \\
\hline 29 & southern magnolia & 57 \\
\hline 30 & Canadian poplar & 64 \\
\hline 31 & Chinese tulip tree & 53 \\
\hline 32 & tangerine & 56 \\
\hline & & \\
\hline
\end{tabular}

Pada penelitian ini digunakan 8 shape feature extraction (ekstraksi feature permukaan) citra daun yaitu:

1. Jumlah titik piksel pada satu area partition.

2. jarak tiap titik pada area partition dengan titik imbang.

3. Jumlah titik piksel pada dekteksi tepi disuatu area.

4. Jarak tiap titik piksel pada deteksi tepi dengan titik berat di satu area.

5. Jumlah titik piksel pada deteksi tepi dan serat daun di satu area partisi.

6. jarak tiap titik piksel pada deteksi tepi dan serat daun dengan titik imbang.

7. Jumlah titik corner/sudut pada satu area partisi.

8. Jarak titik corner/ sudut dengan titik imbang di satu partisi.

Feature vektor extractio tersebut disimpan kedalam suatu file untuk proses trainning dan testing BPNN.

\section{B. ANGULAR PARTITION (AP)}

Angular partition adalah membagi citra daun dengan sudut tertentu, titik pusat yang dipakai adalah titik berat dari citra daun seperti pada Gambar 1 .

Pada penelitian ini digunakan 8 ekstraksi fiture yaitu menghitung jumlah piksel pada luas, keliling, serat, jumlah gerigi serta jarak semua piksel-piksel tersebut dengan titik berat citra daun. Data set dan feature vektor yang dihasilkan dengan 8 ekstraksi feature tersebut tampak pada Tabel II.

$$
\begin{aligned}
& \text { ytotal }=\frac{\sum_{i=1}^{225}\left(\sum_{k=1}^{300} j \text { umlah titik pada }(i, k)\right) * i}{\text { total isi }} \\
& \text { xtotal }=\frac{\sum_{i=1}^{300}\left(\sum_{k=1}^{225} \text { jumlah titik pada }(k, i)\right) * i}{\text { total isi }}
\end{aligned}
$$

Pada persamaan (1) dan (2) xtotal adalah posisi titik berat pada sumbu $\mathrm{X}$, ytotal adalah posisi titik berat pada sumbu Y, sedangkan totalisi adalah jumlah piksel pada citra daun. Persamaan untuk mencari jarak diantara dua titik:

$$
r=\sqrt{(x \text { total }-x 2)^{2}+(y \text { total }-y 2)^{2}}
$$

Pada persamaan (3) r adalah jarak antara (xtotal,ytotal) dengan titik (x2,y2), x2 adalah nilai sumbu $\mathrm{X}$ pada titik yang dicari, y2 adalah nilai sumbu $Y$ pada titik yang dicari, xtotal dan ytotal adalah titik dari titik imbang.

Potongan pertama adalah potongan yang berasal dari garis yang dibuat dengan mencari titik terjauh citra daun dengan titik berat dari citra dan berputar searah jarum jam terlihat pada Gambar 4.

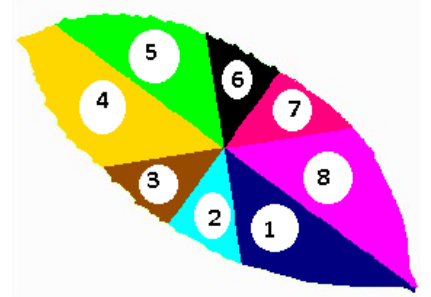

Gambar 4. Urutan Potongan Citra Daun dengan Angular Partition $45^{\circ}$

Ekstraksi fiture daun dengan menggunakan angular partition ini memiliki kelebihan diantaranya adalah citra daun yang hendak dipakai untuk pengujian dapat di flip, diresize dan dirotasi, masih dapat diklasifikasikan dengan benar.

Pada penelitian ini hanya menggunakan shape feature extraction, tidak menambah dengan texture dan color extraction. Sehingga proses learning machine untuk mengklasifikasi citra daun yang dilakukan oleh komputer dirasa cepat dan ringan.

\begin{tabular}{|c|c|c|}
\hline $\begin{array}{c}\text { SUDUT } \\
\text { PEMBAGI }\end{array}$ & $\begin{array}{c}\text { DATA SET (8 EKSTRAKSI } \\
\text { FEATURE) }\end{array}$ & $\begin{array}{c}\text { FEATURE } \\
\text { VEKTOR (1907 } \\
\text { citra) }\end{array}$ \\
\hline 5 & $72 * 8=576$ & 1.098 .432 \\
\hline 11.5 & $32 * 8=256$ & 488.192 \\
\hline 22.5 & $16 * 8=128$ & 244.096 \\
\hline 30 & $12 * 8=96$ & 183.072 \\
\hline 45 & $8 * 8=64$ & 122.048 \\
\hline 90 & $4 * 8=32$ & 61.024 \\
\hline
\end{tabular}

TABEL II

PEMBAGIAN DATA SET \& FEATURE VECTOR

\section{BACKPROPAGATION NEURAL NETWORK}

BackPropagation Neural Network adalah meliputi proses forward pass dan backward pass. Sebuah input akan dimasukkan pada layer neural network secara forward untuk menghasilkan suatu target yang telah ditetapkan, hal ini memunculkan suatu nilai error loss jika target tersebut tidak terpenuhi, dilakukan back pass kedalam layer neural network kembali dengan merubah gradien untuk menghasilkan error lost terkecil. Metode pelatihan yang diawasi (supervised learning), dalam pengertian pelatihan ini mempunyai target yang akan dihasilkan. Ciri dari Backpropagation adalah meminimalkan error pada output yang dihasilkan oleh jaringan dengan cara mengubah 


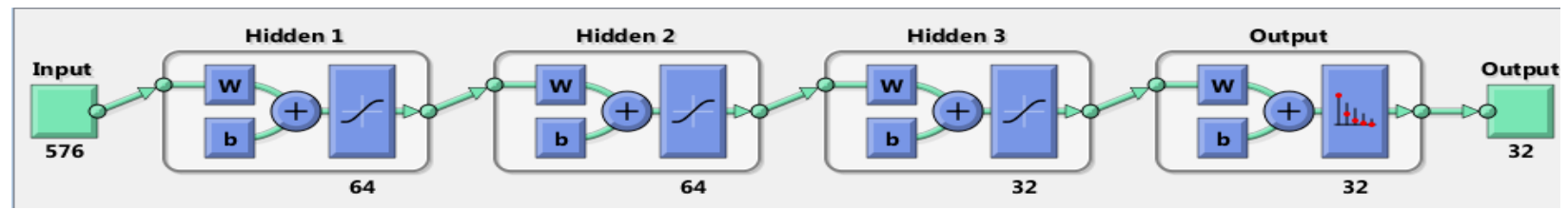

(a)

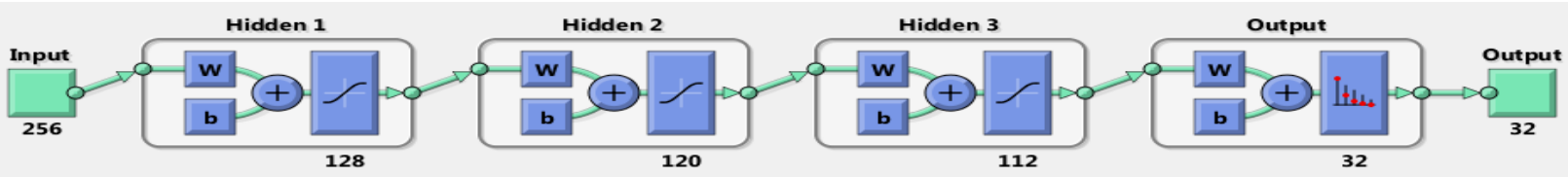

(b)

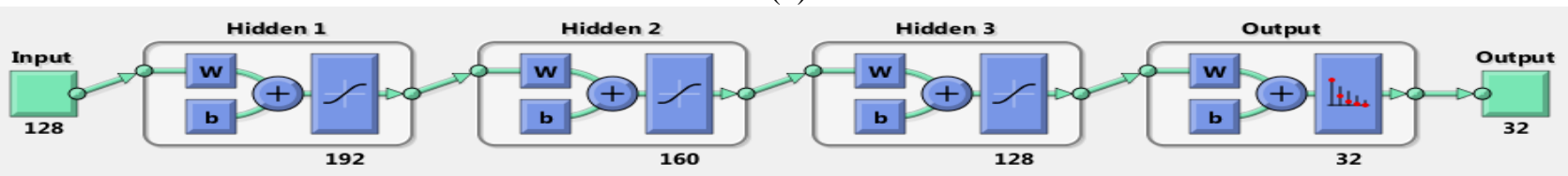

(c)

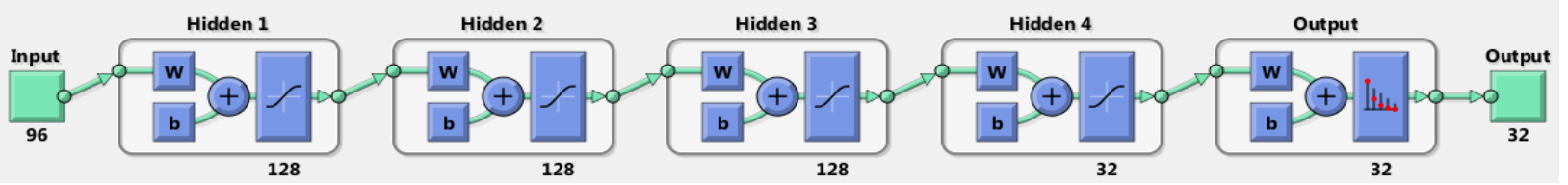

(d)

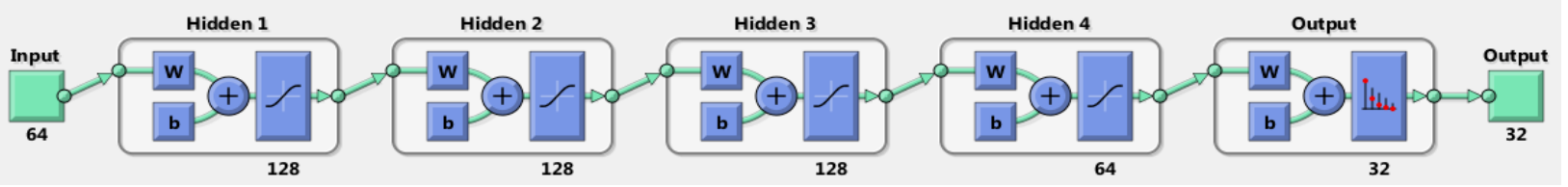

(e)

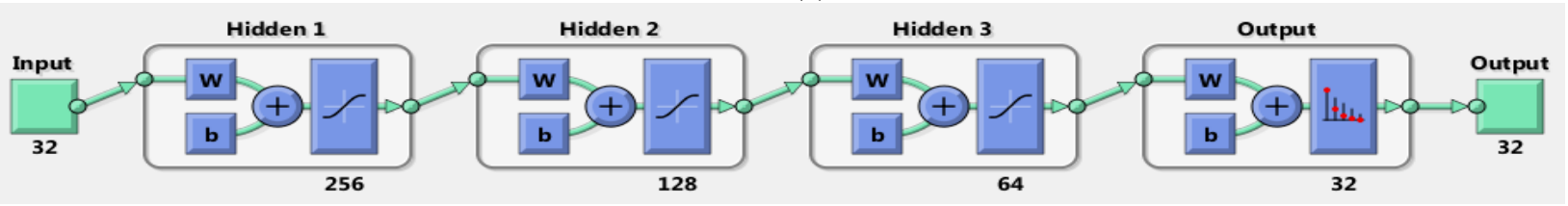

(f)

Gambar 6. Susunan Hidden Layer: (a)untuk AP $5^{\circ}$, (b) untuk AP $11.25^{\circ}$, (c) untuk AP 22.5 ${ }^{\circ}$, (d) untuk AP $30^{\circ}$, (e) untuk AP $45^{\circ}$, (f) untuk AP $90^{\circ}$

gradien. Pada metode backpropagation, seringkali mempunyai susunan dengan jaringan multilayer.[7]

Untuk mencari nilai akurasi tertinggi tidak ada rumusan tentang berapa jumlah hidden layer serta jumlah neuron yang terdapat pada tiap multilayer, sehingga pada dilakukan eksperimen 100 variasi susunan layer neural network untuk setiap angular partition.

Trainning yang digunakan adalah SCG (Scaled Conjugate Gradient) yang berfungsi untuk memperbarui bobot dan meminimalkan error yang terjadi. Inisialisasi scg ini berupa 400 epoch, 287 max-fail, minimum gradien 1e-3.

\section{Perbandingan Waktu Trainning Data.}

Penelitian ini menghasilkan data feature vector dari 1907 citra daun dan dilanjutkan kedalam proses pembelajaran untuk mengklasifikasikan citra daun dengan BPNN maka didapat akurasi tertinggi untuk angular partition (AP) $11.25^{\circ}$ dan $22.5^{\circ}$ adalah sama, sebesar $96,75 \%$.

Dalam pengujian waktu tercepat yang dimulai saat program dijalankan didapat bahwa untuk sudut $11.25^{\circ}$ ( \pm 86 detik) adalah yang terbaik dan tercepat dibandingkan mengunakan angular partition $22.5^{\circ}$ ( \pm 100 detik) seperti yang terlihat pada Tabel III.

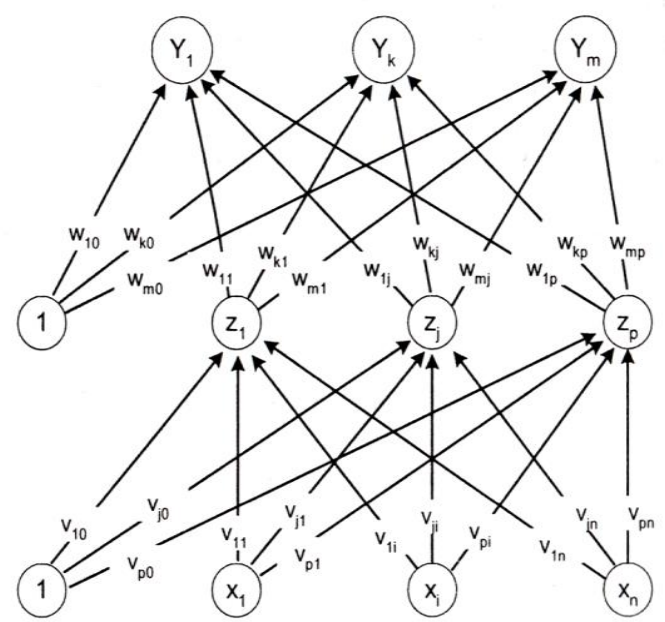

Gambar 5. BackPropagation Neural Network

Perhitungan waktu tersebut untuk mengetahui waktu trainning mana yang tercepat, waktu yang dihasilkan sangat tergantung dari specifikasi hardware, software, besar AP yg ditrainningkan, dan jumlah neuron didalam NN yang berjalan saat proses. 
TABEL III

AKURASI dan WAKTU

\begin{tabular}{|c|c|c|}
\hline $\begin{array}{c}\text { SUDUT } \\
\text { PEMBAGI }\end{array}$ & AKURASI & $\begin{array}{c}\text { WAKTU } \\
\text { (DETIK) }\end{array}$ \\
\hline $5^{\circ}$ & $96,49 \%$ & \pm 131 \\
\hline $11.25^{\circ}$ & $96,75 \%$ & \pm 86 \\
\hline $22.5^{\circ}$ & $96,75 \%$ & \pm 100 \\
\hline $30^{\circ}$ & $95,75 \%$ & \pm 73 \\
\hline $45^{\circ}$ & $94,76 \%$ & \pm 74 \\
\hline $90^{\circ}$ & 82,28 & \pm 81.2 \\
\hline
\end{tabular}

Perhitungan akurasi didapat dengan persamaan 4, TP (true positif) adalah jumlah citra yang diklasifikasikan dengan benar,

$$
\text { AKURASI }=\frac{T P}{\text { jumlah citra daun }} * 100 \%
$$

Pada Gambar 6, tampak jumlah hidden layer dan jumlah Susunan Neural Network yang digunakan untuk trainning, validating dan testing beserta jumlah neuron didalamnya untuk tiap angular partition

TABEL IV

JUMLAH CITRA DAUN YANG DIKLASIFIKASI DENGAN BENAR

\begin{tabular}{|c|c|c|c|c|c|c|c|c|}
\hline \multirow[t]{2}{*}{ No. } & \multirow{2}{*}{$\begin{array}{l}\text { Common } \\
\text { Name(s) }\end{array}$} & \multirow{2}{*}{$\begin{array}{l}\text { Jumlah } \\
\text { Daun }\end{array}$} & \multicolumn{6}{|c|}{$\begin{array}{c}\text { Angular Partition yang } \\
\text { digunakan }\end{array}$} \\
\hline & & & 5 & 11.25 & 22,5 & 30 & 45 & 90 \\
\hline 1 & pubescent bamboo & 59 & 59 & 59 & 59 & 58 & 57 & 52 \\
\hline 2 & $\begin{array}{c}\text { Chinese horse } \\
\text { chestnut }\end{array}$ & 63 & 61 & 60 & 59 & 59 & 59 & 51 \\
\hline 3 & Chinese redbud & 72 & 71 & 71 & 71 & 69 & 71 & 60 \\
\hline 4 & true indigo & 73 & 71 & 73 & 73 & 72 & 73 & 71 \\
\hline 5 & Japanese maple & 56 & 52 & 52 & 55 & 53 & 54 & 48 \\
\hline 6 & Nanmu & 62 & 58 & 57 & 56 & 60 & 59 & 51 \\
\hline 7 & castor aralia & 52 & 51 & 50 & 48 & 52 & 49 & 43 \\
\hline 8 & goldenrain tree & 59 & 59 & 59 & 58 & 58 & 58 & 54 \\
\hline 9 & Chinese cinnamon & 55 & 54 & 49 & 49 & 49 & 46 & 40 \\
\hline 10 & Anhui Barberry & 65 & 62 & 65 & 63 & 62 & 61 & 53 \\
\hline 11 & Big-fruited Holly & 50 & 48 & 46 & 49 & 46 & 42 & 39 \\
\hline 12 & $\begin{array}{c}\text { Japanese } \\
\text { cheesewood }\end{array}$ & 63 & 61 & 63 & 61 & 63 & 56 & 54 \\
\hline 13 & wintersweet & 52 & 48 & 50 & 47 & 49 & 51 & 43 \\
\hline 14 & camphortree & 65 & 63 & 62 & 63 & 63 & 57 & 46 \\
\hline 15 & Japan Arrowwood & 60 & 53 & 58 & 57 & 54 & 57 & 38 \\
\hline 16 & sweet osmanthus & 56 & 56 & 52 & 55 & 55 & 52 & 39 \\
\hline 17 & deodar & 77 & 77 & 77 & 77 & 77 & 76 & 69 \\
\hline 18 & $\begin{array}{c}\text { ginkgo, } \\
\text { maidenhair tree }\end{array}$ & 62 & 60 & 61 & 62 & 60 & 61 & 53 \\
\hline 19 & Crape myrtle & 61 & 61 & 59 & 60 & 58 & 60 & 47 \\
\hline 20 & oleander & 66 & 64 & 65 & 66 & 64 & 63 & 55 \\
\hline 21 & yew plum pine & 60 & 59 & 60 & 58 & 59 & 59 & 51 \\
\hline 22 & $\begin{array}{c}\text { Japanese } \\
\text { Flowering Cherry }\end{array}$ & 55 & 53 & 52 & 55 & 52 & 54 & 51 \\
\hline 23 & Glossy Privet & 55 & 51 & 54 & 54 & 53 & 53 & 41 \\
\hline 24 & Chinese Toon & 65 & 64 & 63 & 63 & 63 & 64 & 58 \\
\hline 25 & peach & 54 & 48 & 51 & 51 & 45 & 44 & 34 \\
\hline 26 & Ford Woodlotus & 52 & 52 & 50 & 48 & 47 & 47 & 32 \\
\hline 27 & trident maple & 53 & 51 & 50 & 50 & 52 & 49 & 48 \\
\hline 28 & Beale's barberry & 55 & 50 & 52 & 55 & 53 & 55 & 51 \\
\hline 29 & southern magnolia & 57 & 56 & 56 & 56 & 54 & 53 & 52 \\
\hline 30 & Canadian poplar & 64 & 62 & 64 & 62 & 63 & 63 & 58 \\
\hline 31 & Chinese tulip tree & 53 & 50 & 50 & 51 & 48 & 52 & 42 \\
\hline 32 & tangerine & 56 & 55 & 55 & 54 & 56 & 52 & 45 \\
\hline
\end{tabular}

\section{PENGUJIAN}

Dalam bagian ini dilakukan beberapa macam pengujian terhadap hasil trainning.

Pada Tabel 4 terdapat data jumlah daun yang dapat dikenali untuk tiap jenis beserta angular partition yang digunakan untuk membentuk ekstraksi fiture.

Pada proses pengujian ini dilakukan beberapa modifikasi citra daun. citra daun yang dimodifiksi adalah citra daun yang awalnya dapat diklasifikasikan dengan benar.

Modifikasi citra daun tersebut meliputi horisontal flip, vertikal flip, dan rotasi image.

Citra daun yang diambil untuk pengujian terdapat pada Gambar 7.

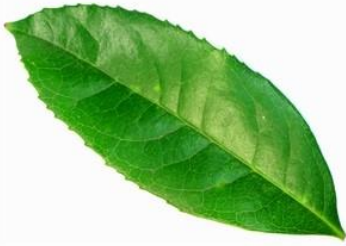

(a)

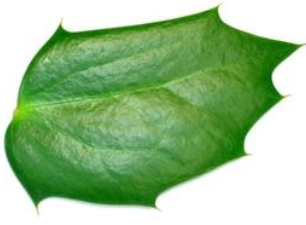

(b)
Gambar 7. Citra Awal

(a) 2331 Sweet Osmanthus, (b) 3345 Beale Barberry.

\section{A. Horisontal Flip.}

Gambar 7(a) dan 7(b) direfleksikan pada sumbu Y, dengan cara mengubah mengubah setiap koordinat piksel citra $f(x, y)$ menjadi $f(-x, y)$.

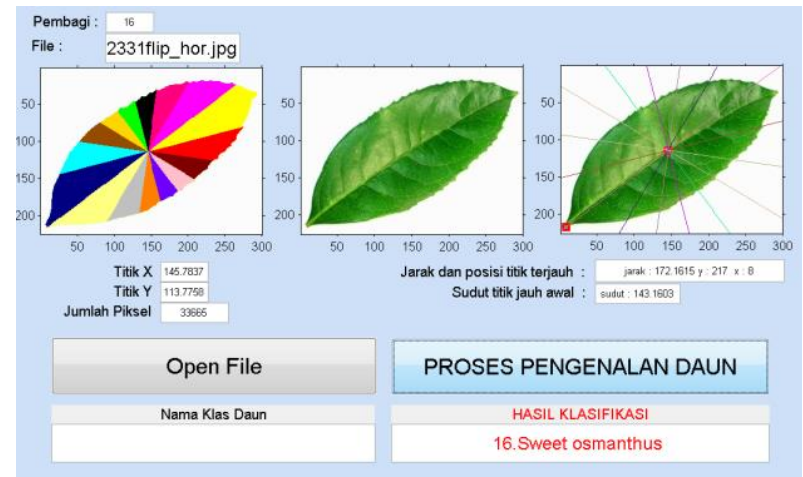

(a)

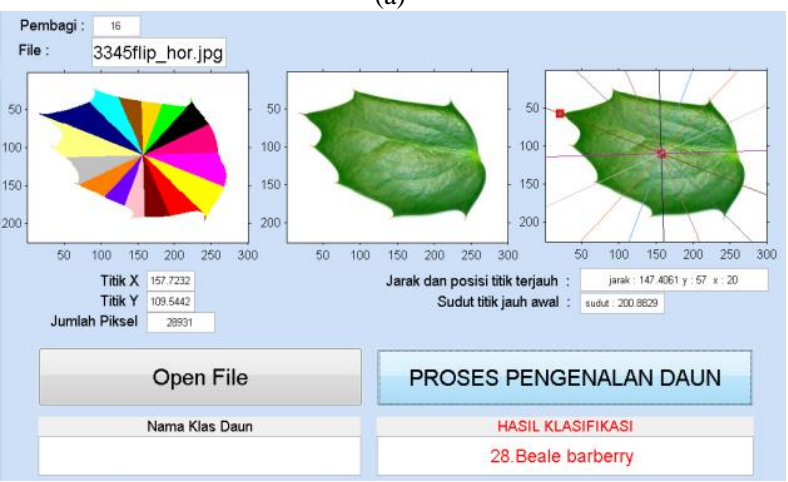

(b)

Gambar 8. Hasil Klasifikasi BPNN Citra Daun di Flip Horisontal (a) 2331 Sweet Osmanthus, (b)3345 Beale Barberry.

Gambar 8(a) adalah pengujian untuk gambar 7(a) yang telah dilakukan proses flip secara horisontal, hasil pengujian tampak bahwa Citra daun 2331 Sweet Osmanthus yang telah di flip horisontal masih dapat diklasifikasikan dengan benar.

Gambar 8(b) adalah pengujian untuk gambar 7(b) yang telah dilakukan proses flip secara horisontal, hasil pengujian tampak bahwa Citra daun 3345 Beale Barberry yang telah di flip horisontal masih dapat diklasifikasikan dengan benar.

\section{B. Vertikal Flip}

Gambar 7(a) dan 7(b) direfleksikan pada sumbu X, dengan cara mengubah koordinat setiap piksel pada citra $f(x, y)$ menjadi $f(x,-y)$. 
Gambar 9(a) adalah pengujian untuk gambar 7(a) yang telah dilakukan proses flip secara vertikal, hasil pengujian tampak bahwa Citra daun 2331 Sweet Osmanthus yang telah di flip vertikal masih dapat diklasifikasikan dengan benar.

Gambar 9(b) adalah pengujian untuk gambar 7(b) yang telah dilakukan proses flip secara vertikal, hasil pengujian tampak bahwa Citra daun 3345 Beale Barberry yang telah di flip vertikal masih dapat diklasifikasikan dengan benar.

\section{Rotasi $90^{\circ}$ searah jarum jam (kekanan)}

Gambar 7(a) dan 7(b) dirotasikan $90^{\circ}$ kekanan dengan ms paint, lalu dilakukan proses pengklasifikasian dengan BPNN.

Gambar 10(a) adalah pengujian untuk gambar 7(a) yang telah dilakukan proses rotasi kekanan $90^{\circ}$, hasil pengujian tampak bahwa Citra daun 2331 Sweet Osmanthus yang telah di rotasi $90^{\circ}$ kekanan masih dapat diklasifikasikan dengan benar.

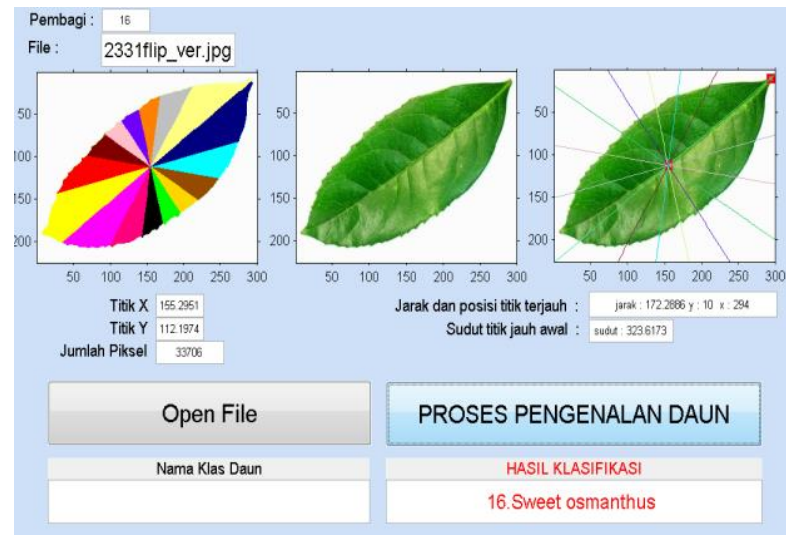

(a)

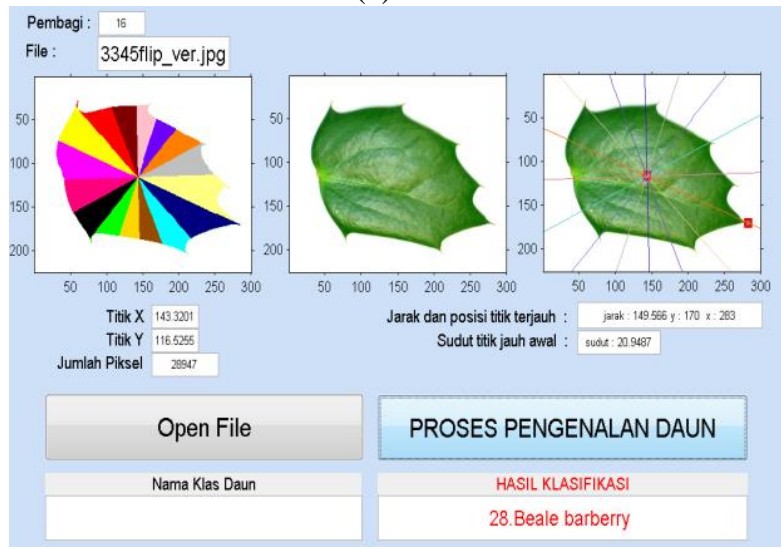

(b)

Gambar 9. Hasil Klasifikasi Citra Daun di Flip Vertikal (a) 2331 Sweet Osmanthus, (b)3345 Beale Barberry

Gambar 10(b) adalah pengujian untuk gambar 7(b) yang telah dilakukan proses rotasi $90^{\circ}$ kekanan, hasil pengujian tampak bahwa Citra daun 3345 Beale Barberry yang telah di rotasi $90^{\circ}$ kekanan masih dapat diklasifikasikan dengan benar.

\section{Rotasi $90^{\circ}$ berlawanan arah jarum jam (kekiri)}

Gambar 7(a) dan 7(b) dirotasikan $90^{\circ}$ kekiri dengan ms paint, lalu dilakukan proses pengklasifikasian dengan BPNN.

Gambar 11(a) adalah pengujian untuk gambar 7(a) yang telah dilakukan proses rotasi kekiri $90^{\circ}$, hasil pengujian tampak bahwa Citra daun 2331 Sweet Osmanthus yang telah di rotasi $90^{\circ}$ kekiri masih dapat diklasifikasikan dengan benar.

Gambar 11(b) adalah pengujian untuk gambar 7(b) yang telah dilakukan proses rotasi $90^{\circ}$ kekiri, hasil pengujian tampak bahwa Citra daun 3345 Beale Barberry yang telah di rotasi $90^{\circ}$ kekiri masih dapat diklasifikasikan dengan benar.

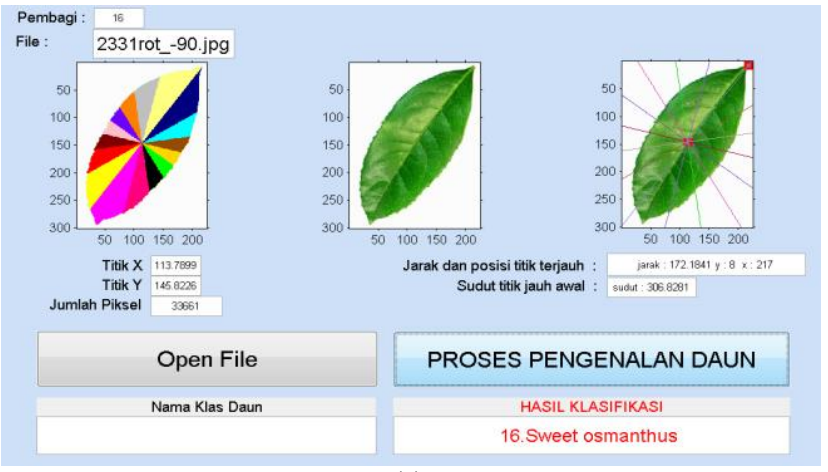

(a)

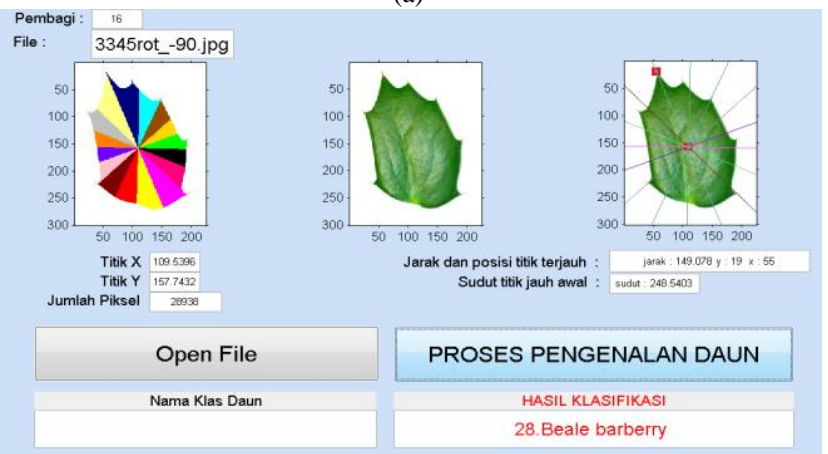

(b)

Gambar 11. Hasil Klasifikasi BPNN Citra Daun di Rotasi $90^{\circ}$ Kekiri (a) 2331 Sweet Osmanthus, (b)3345 Beale Barberry

\section{E. Pengujian dengan Meresize Citra Daun}

Pengujian ini dilakukan dengan mengecilkan citra daun menjadi 50\% dan membesarkan citra daun sebesar $150 \%$ dari citra asal. Pada Gambar 12(a), (b),(c) dan (d) terlihat bahwa dengan angular partition untuk membuat dataset, citra daun masih dapat diklasifikasikan dengan benar.

TABEL V

PERBANDINGAN AKURASI

\begin{tabular}{|l|c|}
\hline \multicolumn{1}{|c|}{ METODE } & AKURASI \\
\hline PNN [1] & $90 \%$ \\
\hline PNN [10] & $93.75 \%$ \\
\hline BPNN [13] (swedish leaf dataset) & $96.53 \%$ \\
\hline PNN [11] (600 citra tumbuhan obat) & $86.19 \%$ \\
\hline Feed Forward NN [6] & $71.4 \%$ \\
\hline Penelitian ini & $96,75 \%$ \\
\hline
\end{tabular}

TABEL VI

AKURASI ANTAR AP

\begin{tabular}{|c|c|}
\hline SUDUT & AKURASI \\
\hline 5 & $96,49 \%$ \\
\hline 11.25 & $96,75 \%$ \\
\hline 22.5 & $96,75 \%$ \\
\hline 30 & $95,75 \%$ \\
\hline 45 & $94,76 \%$ \\
\hline 90 & 82,28 \\
\hline
\end{tabular}




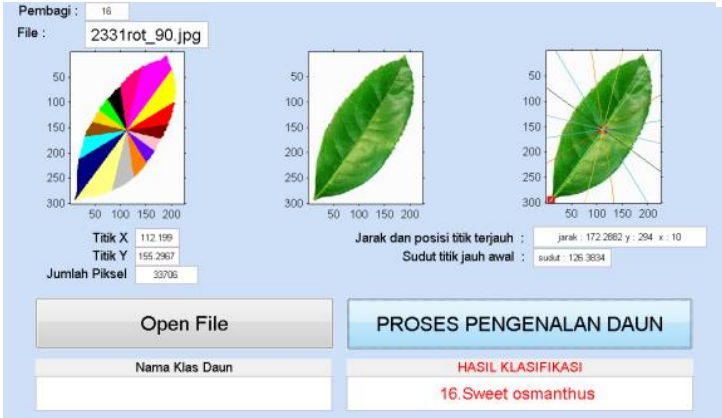

(a)

Gambar 10. Hasil Klasifikasi BPNN Citra Daun diRotasi $90^{\circ}$ kekanan

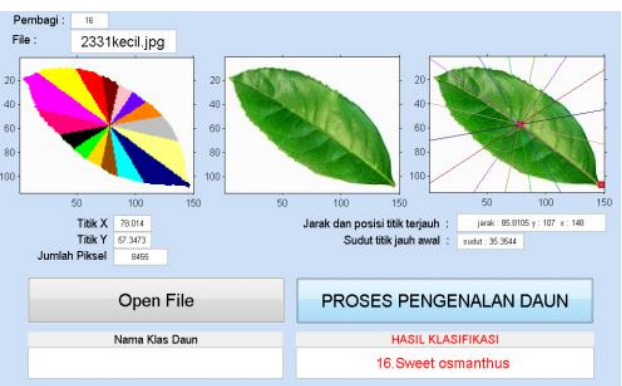

(a)

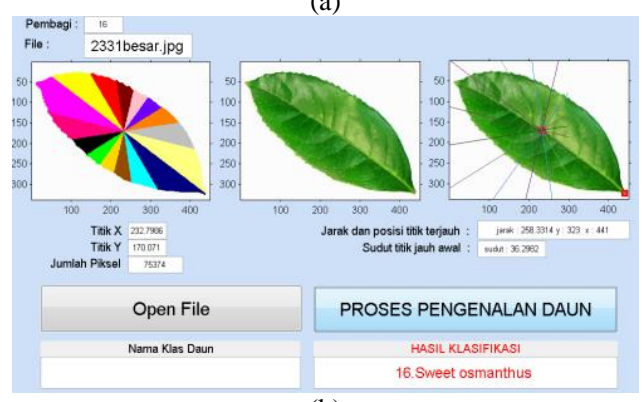

(b)

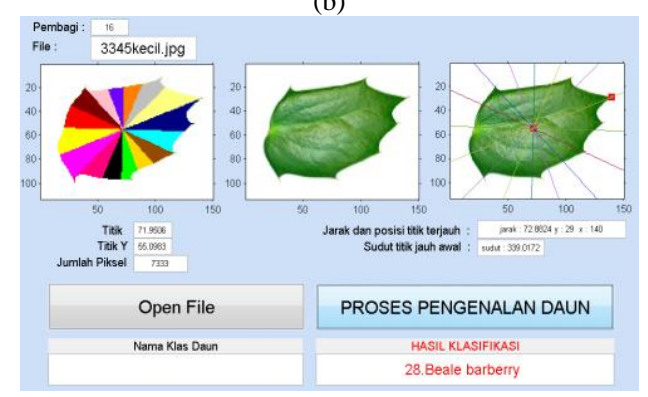

(c)

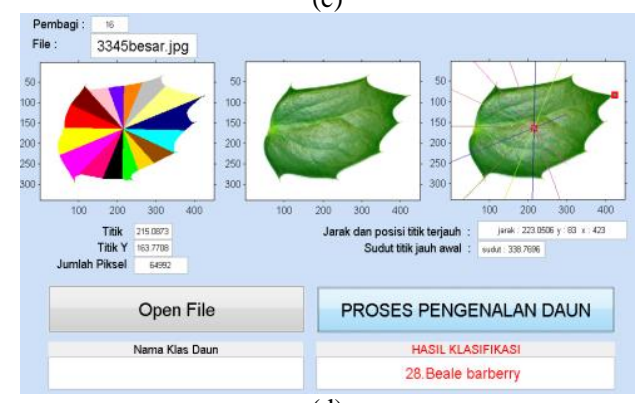

(d)

Gambar 12. Hasil Klasifikasi BPNN Citra Daun diresize.

(a) 2331 dikecilkan $50 \%$, (b) 2331 diperbesar $150 \%$

(c)3345 dikecilkan 50\%, (d) 3345 diperbesar $150 \%$

\section{KESIMPULAN}

Kesimpulan yang didapat dari penelitian ini adalah

- Metode BackPropagation Neural Network dapat dipakai untuk mengklasifikasikan citra daun dengan tingkat

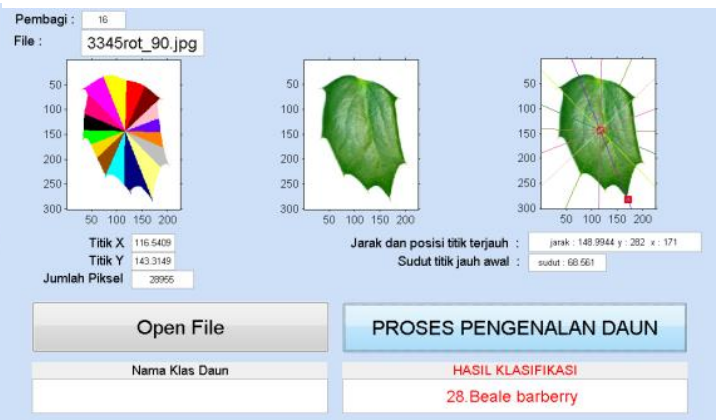

(b)

(a) 2331 Sweet Osmanthus, (b)3345 Beale Barberry

akurasi yang tinggi yaitu sebear 96,75\% dengan Angular Partition sebesar $11,25^{\circ}$ dan $22,5^{\circ}$.

- Ekstraksi feature dengan Angular Partition memiliki kelebihan yaitu citra dapat di flip secara horisontal maupun vertikal, dapat dirotate kekanan 90 maupun kekiri 90, serta dapat diresize baik dikecilkan 50\% maupun diperbesar $150 \%$. Seperti yang tampak pada Gambar 8,9,10,11, dan 12

- Pada Tabel 5 tampak bahwa semakin besar angular partition menyebabkan ciri-ciri dari citra daun menjadi bias, sedangkan semakin kecil angular partition, ciri-ciri dari citra daun semakin tidak terlihat.

\section{DAFTAR PUSTAKA}

[1]S. G. Wu, F. S. Bao, E. Y. Xu, Y. X. Wang, Y. F. Chang, and Q. L. Xiang, "A leaf recognition algorithm for plant classification using probabilistic neural network," ISSPIT 2007 - 2007 IEEE Int. Symp. Signal Process. Inf. Technol., pp. 11-16, 2007

[2]A. Chalechale, G. Naghdy, and A. Mertins, "Sketch-based image matching using angular partitioning," IEEE Trans. Syst. Man, Cybern. Part ASystems Humans., vol. 35, no. 1, pp. 28-41, 2005.

[3]N. (New J. I. of T. Ravindra, L. (New J. I. of T. Buss-Alexander, H. (New J. I. of T. McCloud, R. D. (New J. I. of T. Rivero, K. (Johns H. U. Ravindra, and J. (Wiliam D. H. S. Misterio, "Variation of Fractal Dimension of Leaves Based on Stem Position,” p. 12, 2007.

[4] Boran Şekeroğlu, Yücel İnan, "Leaf Recognition System Using Neural Network, Procedia Computer Science,vol. 10, pp. 578-582, August, 2016

[5] Y. LeCun et al., "Backpropagation Applied to Handwritten Zip Code Recognition," Neural Computation, Vol. 1, No. 4, hal. 541-551, 1989.

[6] Y. Ye, C. Chen, C.-T. Li, H. Fu, and Z. Chi, "A computerized plant species recognition system," in Proceedings of 2004 International Symposium on Intelligent Multimedia, Video and Speech Processing, Hong Kong, October 2004.

[7] Aurélien Géron, "Hands-On Machine Learning With Scikit-Learn \& TensorFlow", 1 st Edition, O'reilly, US, 2017

[8] Simon Haykin, "Neural Network A Comprehensive Foundation", 2 ${ }^{\text {nd }}$ Edition, Prentice Hall, 2001.

[9] B. S. Bama, S. M. Valli, S. Raju, and V. A. Kumar, "Conten based leaf image retrieval using shape, color and texture features", Indian Journal of Computer Science and Engineering, vol. 2, no. 2, 2011, pp. 202-211

[10] A.Kadir,Lukito E.N, Adhi N, "Leaf Classification Using Shape, Color, and Texture Features", International Journal of Computer Trends and Technology, July to Aug, 2011.

[11] D. A. Ratu, "Ekstraksi Daun Menggunakan Dimensi Fraktal untuk Identifikasi Tumbuhan Obat di Indonesia.” Dep. ILMU Komput. Fak. Mat. DAN ILMU Pengetah. ALAM Inst. Pertan. BOGOR, 2011.

[12] K. Verma, L. K. Verma, and P. Tripathi, "Image Classification using Backpropagation Algorithm," Journal of Computer Science, July 2014.

[13] I. Yahiaoui and A. Verroust-blondet, "A shape-based approach for leaf classification using multiscale triangular representation To cite this version: A shape-based approach for leaf classification using multiscale triangular representation.," 2013.

Elkana Lewi Santoso (elkanaliu@gmail.com) lahir di Surabaya tahun 1973, Jawa Timur, Indonesia. Lulus S1 di Sekolah Tinggi Teknologi Cahaya Surya Kediri tahun 2000. Aktif Mengajar di STT Cahaya Surya Kediri tahun 2000-sekarang. Fokus pada bidang Networking, Operating System, Neural Network. 